\title{
Analisis Aktor Pelaksana Dalam Implementasi Program Bantuan Sosial Beras Sejahtera Di Kelurahan Kasongan Baru Kecamatan Katingan Hilir Kabupaten Katingan
}

\section{Analysis of implementing actors in the implementation of the social rice assistance Program in Kasongan New district of Katingan downstream of Katingan Regency}

\section{Riban Satia* \\ Risdayanti Noor Safitri}

Universitas Muhammadiyah Palangkaraya, Palangka Raya, Central Kalimantan, Indonesia

email: mribansatia@gmail.com

\author{
Kata Kunci: \\ Aktor Pelaksana \\ Keluarga Penerima Manfaat \\ Bantuan Sosial \\ Beras Sejahtera
}

\section{Keywords:}

Implementing actors

Family beneficiaries

Social assistance

Prosperous rice

\section{Accepted}

January 2018

\begin{abstract}
Abstrak
Tujuan penelitian ini untuk mengetahui bagaimana peran aktor dalam Implementasi Program Bantuan Beras Sejahtera di Kelurahan Kasongan Baru Kecamatan Katingan Hilir Kabupaten Katingan. Adapun metode penelitian yang digunakan bersifat deskriptif kualitatif yaitu untuk menerangkan, menggambarkan, dan melukiskan suatu fenomena yang ada untuk memecahkan suatu masalah. Dalam penelitian ini terdapat dua sumber data, yaitu sumber data primer yang diperoleh dari hasil wawancara dengan beberapa responden di Kelurahan Kasongan Baru, dan sumber data sekunder diperoleh dari berbagai dokumen dan lain sebagainya.

Berdasarkan hasil penelitian dapat disimpulkan bahwa peran aktor dalam pelaksanaan Implementasi Program Bantuan Sosial Beras Sejahtera di Kelurahan Kasongan Baru masih belum berjalan dengan baik jika dilihat dari komunikasi dan sasaran Keluarga Penerima Manfaat. Dari permasalahan yang ada peneliti menyarankan agar pegawai Kelurahan lebih sering berkomunikasi lagi dengan masyarakat yang ada di kelurahan Kasongan Baru, khususnya Keluarga Penerima Manfaat Bantuan Sosial Beras Sejahtera serta Dinas Sosial lebih menekankan lagi kepada setiap Kelurahan atau Desa agar mendata masyarakat yang masuk dalam kriteria penerima manfaat Bantuan Sosial Beras Sejahtera agar data yang ada dapat diperbaharui dan tercapainya tujuan dari Bantuan Sosial Beras Sejahtera di Kabupaten Katingan.
\end{abstract}

Published

April 2018

\begin{abstract}
The purpose of this research is to know how actors role in the implementation of the Rice prosperous assistance Program in the new Kasongan sub-district of Katingan Hilir Katingan regency. The research method used is a qualitative descriptive that is to explain, describe, and represent a phenomenon that exists to solve a problem. In this study there are two data sources, namely the primary data source obtained from interviews with several respondents in the new village of Kasongan, and secondary data sources are obtained from various documents and so on.

Based on the results of the study can be concluded that the role of actors in implementing the implementation of the social rice assistance Program in Kasongan New village is still not going well if viewed from the communication and target of the recipient family Benefits. From the problem that the researcher suggested that the village employees more often communicate with the community in Kasongan New village, especially the beneficiaries family of social and social assistance Emphasize again to each Kelurahan or village in order to record the community that is included in the criteria of beneficiaries social rice assistance so that the data can be renewed and the achievement of the purpose of the social assistance of the prosperous rice in Katingan.
\end{abstract}

\section{PENDAHULUAN}

Pembangunan yang selama ini dilakukan oleh pemerintah cukup membawa kemajuan secara umum dan memberikan dampak yang baik dalam beberapa aspek kehidupan, akan tetapi pencapaian pembangunan tersebut belum merata sehingga tidak semua masyarakat bisa menikmati hasil dari pembangunan tersebut terutama yang masih berada di bawah garis kemiskinan. 
Negara Indonesia mempunyai tanggung jawab terhadap kemiskinan karena ini merupakan amanah konstitusi sebagaimana tercantum dalam Undang-Undang Dasar tahun 1945 pasal 34 (I) yang berbunyi "Fakir miskindan anak terlantar dipelihara oleh Negara". Ketentuan ini lebih diperjelas lagi dalam UndangUndang No.I3 tahun 2011 tentang Penanganan Fakir Miskin dimana Negara mempunyai kewajiban memenuhi kebutuhan dasar yang layak bagi kehidupan fakir miskin dan keluarganya.

Peran dari pemerintah sangat diperlukan, mengingat kebijakan dan peraturan yang dibuat menjadi acuan dalam mendorong kearah pembangunan. Salah satu program yang dibentuk oleh pemerintah untuk mengurangi beban masyarakat dalam pemenuhan kebutuhan pokok adalah Program Bantuan Sosial Beras Sejahtera (Bansos Rastra). Program Bansos Rastra adalah kebijakan transformasi Program Subsidi Raskin/ Rastra menjadi Program Bantuan Sosial Pangan. Program Bansos Rastra diselenggarakan oleh pemerintah, dalam rangka untuk meningkatkan efektivitas dan efisiensi, ketepatan sasaran penyaluran bantuan sosial.

Namun pada pelaksanaan program Bansos Rastra terdapat beberapa permasalahan yaitu: Pertama, dapat dilihat dari indikator tepat sasaran, yang dimana masih terdapat rumah tangga yang seharusnya menerimaBansos Rastra, akan tetapi tidak terdaftar menjadi Keluarga Penerima Manfaat (KPM), sehingga masyarakat tidak mendapat Bantuan Sosial Beras Rastra tersebut. Sementara itu juga terdapat rumah tangga yang tidak berhak untuk menerima Bansos Rastra, justru menerima bantuan tersebut. Kedua, untuk indikator tepat waktu masih sering terjadi keterlambatan dalam pendistribusian bahan pangan, yang dimana pendistribusian tersebut seharusnya dilakukan setiap bulan.

Edward III dan Sharkansy (2007:16) mengemukakan Kebijakan publik adalah apa yang dinyatakan dan dilakukan atau tidak dilakukan oleh pemerintah. Kebijakan publik berupa sasaran atau tujuan program pemerintah. kebijakan publik itu dapat ditetapkan secara jelas dalam peraturan perundang-undangan, atau dalam bentuk pidato pidato pejabat pemerintah ataupun berupa program-program dan tindakantindakan yang dilakukan pemerintah.

Model implementasi kebijakan yang akan penulis gunakan dalam penelitian ini yaitu dari George C Edward III disebut dengan Direct and Indirec inpac on Implementation. Dalam pendekatan yang diterjemahkan oleh Edward III, terdapat empat aspek yang sangat mempengaruhi keberhasilan implementasi kebijakan, yaitu aspek komunikasi, sumberdaya, disposisi dan struktur birokrasi.

Didalam implementasi kebijakan akan selalu ada yang dinamakan dengan aktor kebijakan publik yang baik berperan dalam pembuatan kebijakan sampai pelaksanaan kebijakan publik itu sendiri. Dan pengertian aktor pembuat kebijakan publik yaitu orang /kelompok orang yang bertugas menganalisis, merumuskan, menyusun kebijakan. Pejabat pembuat kebijakan adalah orang yang mempunyai wewenang yang sah untuk ikut serta dalam formulasi hingga penetapan kebijakan publik, walau dalam kenyataannya beberapa orang yang mempunyai wewenang sah untuk bertindak dikendalikan oleh orang lain.

Sedangkan Husnul Yakin (201 I:95) mengatakan bahwa ada 4 unsur yang perlu diperhatikan dalam mengetahui faktor penentu keberhasilan peran para aktor dalam implementasi suatu kebijakan yaitu: I)Partisipasi aktor, yaitu dengan menilai bagaimana peran aktoraktor terkait dalam pelaksanaan suatu kebijakan. 2) Perspektif aktor, yaitu dengan menilai bagaimana aktor-aktor memahami program. 3)Aksesibilitas aktor, yaitu dengan menilai bagaimana akses aktor-aktor dalam pelaksanaan program. 4) Penentuan tindakan, yaitu dengan menilai bagaimana peran aktor dalam menentukan tindakan. 


\section{METODOLOGI}

Jenis penelitian yang digunakan dalam penelitian ini, menggunakan penelitian deskriptif, karena menggambarkan secara tepat mengenai keadaan atau realita yang terjadi di dalam masyarakat. Sedangkan pendekatan yang digunakan adalah pendekatan kualitatif. Jadi, penulisan dalam penelitian ini menggunakan metode deskriptif kualitif.

Dalam penelitian ini ada dua jenis sumber data yaitu sumber data primer dan sekunder. Yang menjadi sumber data primer/informan utama dalam penelitian ini adalah Lurah Kasongan Baru, pelaksana dan pengawas distribusi di Kelurahan Kasongan Baru, serta Keluarga Penerima Manfaat Bantuan Sosial Beras Sejahtera (Bansos Rastra) di Kelurahan Kasongan Baru Kecamatan Katingan Hilir, Kabupaten Katingan.

\section{HASIL DAN PEMBAHASAN}

Ditemukan beberapa hal yang terjadi dalam Implementasi Program Bantuan Sosial Beras Sejahtera di Kelurahan Kasongan Baru Kecamatan Katingan Hilir Kabupaten Katingan jika dilihat dari 4 aspek yang mempengaruhi keberhasilan implementasi kebijakan :

a. Komunikasi

Jika dilihat dari Komunikasi dalam Implementasi Program Bantuan Sosial Beras Sejahtera di Kelurahan Kasongan Baru, sudah berjalan sesuai dengan ketentuan tetapi memang masih ada beberapa kendala dikarenakan masih kurangnya komunikasi dari pihak pelaksana dengan KPM. Tidak adanya sosialisasi kepada masyarakat tentang Beras Sejahtera, jadi banyak masyarakat yang tidak paham tentang tujuan dan sasaran dari Program Bansos Rastra sedangkan di dalam Pedoman Umum Rastra tahun 2018 tertulis bahwa di setiap Kecamatan/ Kelurahan/Desa harus mengadakan sosialisasi kepada masyarakat khususnya Keluarga Penerima Manfaat. Keluarga Penerima Manfaat hanya mengetahui bahwa KPM tersebut terdaftar sebagai penerima Beras Sejahtera setelah ada DPM yang disampaikan oleh Kementerian Sosial kepada Pemerintah Daerah melalui Aplikasi SIKS-NG untuk di sampaikan kepada Dinas Sosial dan Kecamatan. Pemberitahuan kepada setiap Keluarga Penerima Manfaat dilakukan ketika Beras Sejahtera sampai di Kantor Kelurahan Kasongan Baru dan Lurah Kasongan Baru akan mengirimkan surat kepada setiap KPM bahwa Beras Sejahtera sudah ada di Kelurahan Kasongan Baru.

b. Sumber Daya

Dilihat dari Sumber Daya dalam Implementasi Program Bantuan Sosial Beras Sejahtera jika dilihat dari sumber daya pegawai Dinas Sosial, Kecamatan Katingan Hilir dan Kelurahan Kasongan Baru yang terlibat dalam pelaksanaan Program Beras Sejahtera ini sudah berjalan sesuai dengan ketentuan dan aturan yang berlaku, hanya saja masih ada beberapa pegawai Kelurahan Kasongan Baru yang masih belum paham akan mekanisme penyaluran Beras Sejahtera ini. Dan jika dari Keluarga Penerima Manfaat itu sendiri, ada beberapa KPM yang kurang tetap sasaran jika dilihat dari kriteria penerima Beras Sejahtera, seharusnya ada beberapa masyarakat yang sesuai dengan kriteria KPM Beras Sejahtera tetapi karena sulitnya perubahan data untuk mengganti KPM membuat kurang tepatnya sasaran Program Bansos Rastra. Saat ingin perubahan/pembaharuan Data Penerima Manfaat Bansos Rastra harus melalui mekanisme Musyawarah Desa/Kelurahan (Mudes/ Muskel) dan/atau Musyawarah Kecamatan (Muscam) dan harus dilakukan pada tahun berjalan/pada tahun pelaksanaan Program Bantuan Sosial Beras Sejatera. 


\section{Setiap Mengadakan Musdes /Kelurahan/} Musyawarah Kecamatan harus dengan melibatkan Ketua RT/RW, tokoh masyarakat, tokoh agama, dan unsur masyarakat lain sesuaidengan kondisi sosial budaya masyarakat setempat serta Pendamping Sosial dan perubahan Data Penerima Manfaat harus melengkap Berita Acara Mudes/Muskel/Muscam, Formulir Rekapitulasi Pengganti (FRP), dan DPM-I. Jika Keluarga Penerima Manfaat Program Beras Sejahtera berganti, paling cepat I tahun Data Penerima Manfaat baru bisa berganti di Pusat dan bisa menerima Beras Sejahtera sesuai KPM yang baru, jadi sangat jarang Data Keluarga Penerima Manfaat Program Beras Sejahtera berganti karena sangat rumitnya persyaratan perubahan Data Penerima Manfaat.

c. Disposisi

Kelurahan Kasongan Baru bukanlah sebagai instansi pihak pelaksana yang utama dalam pelaksanaan Program Bantuan Sosial Sejahtera, tetapi Kelurahan berperan penting dalam Pelaksanaan Program Bansos Rastra dikarenakan Kelurahan yang dapat mengajukan pergantian/ perubahan Data Penerima Manfaat Beras Sejahtera dan Kelurahan lah yang menyalurkan Beras untuk setiap Keluarga Penerima Manfaat. Kelurahan berperan penting dalam sampai atau tidaknya Beras Sejahtera ke setiap KPM dan tepat atau tidak sasaran dari setiap penerima KPM Beras Sejahtera.

Data yang digunakan dalam Program Bansos Rastra di Kecamatan Katingan Hilir masih memakai data tahun 20I3, sudah berjalan 5 tahun dengan KPM yang sama setiap tahunnya. Dan waktu penerimaan Beras Sejahtera yang seharusnya jika dilihat dari Pedoman Umum Rastra tahun 2018, setiap KPM menerima 10 kgsetiap bulannya tetapi dalam penyaluran Bansos Rastra ke setiap Kelurahan dan Desa tidak dapat dilakukan secara rutin setiap bulan karena kebijakan daerah dan/atau kendala antara lain kondisi geografis, iklim/cuaca, hambatan transportasi, maka Tim Koordinasi Bansos Pangan Kabupaten/Kota mengajukan usulan perubahan waktu penyaluran Bansos Rastra kepada Kementerian Sosial untuk mendapatkan persetujuan dengan tembusan kepada Tim Koordinasi Bansos Pangan Provinsi. Jadi seluruh Keluarga Penerima Manfaat di Kelurahan Kasongan Baru menerima Beras Sejahtera dengan cara perapelan, Beras Sejahtera yang sudah di terima di Kelurahan Kasongan Baru sudah di berikan sebanyak 12 bulan.

d. Struktur Birokrasi

Implementasi Program Bantuan Beras Sejahtera di Kelurahan Kasongan Baru tentunya melibatkan banyak pihak diantaranya Pemerintah Provinsi, Pemerintah Kabupaten Katingan serta Kecamatan Katingan Hilir baik itu dari pendataan bahkan sampai penyaluran ke Titik Distribusi (TD) dan tidak ada kekurangan dalam sumber daya pegawai baik dari Dinas Sosial dan Kecamatan Katingan Hilir saat penyaluran Beras Sejahtera ke setiap Kelurahan dan Desa.

Jika dalam penyalurannya di Kelurahan Kasongan Baru tidak ada penyimpangan dari pegawai Kelurahan baik saat menerima beras dari Kecamatan Katingan Hilir sampai saat beras diserahkan ke setiap Keluarga Penerima Manfaat dan setiap Keluarga Penerima Manfaat selalu menerima beras sesuai jumlahnya dan tidak adadikenakan biaya apapun. Dan kualitas beras yang diberikan kepada Keluarga Penerima Manfaat sudah bagus dan layak di konsumsi.

\section{Peran Aktor dalam Implementasi Bansos Rastra di Kelurahan Kasongan Baru}

Proses implementasi program Bantuan Sosial

Beras Sejahtera di Kelurahan Kasongan Baru 
merupakan suatu proses penyaluran beras kepada Keluarga Penerima Manfaat untuk mencapai tujuan dari adanya Program Bantuan Beras Sejahtera itu sendiri dengan menjadikannya Kecamatan Katingan Hilir dan Kelurahan Kasongan baru sebagai Aktor dalam proses penyalurannya kepada masyarakat. Jika di Kecamatan Katingan Hilir ada Kasi Pembedayaan Masyarakat dan Desa yang bertugas mengurus berkas pemberitahuan pendistribusian ke setiap Kelurahan dan Desa serta mengarahkan beras ke setiap tempat pendistribusian yang di siapkan Kelurahan dan Desa, dan jika ada terdapat masalah serta keluhan atau ada yang ingin setiap Kelurahan atau Desa tanyakan terkait Bantuan Sosial Beras Sejahtera dapat menghubungi Kasi Pemberdayaan Masyarakat dan Desa Kecamatan Katingan Hilir.

Di Kelurahan yang mengurus masalah kedatangan sampai pembagian ke setiap Keluarga Penerima Manfaat yaitu Kasi Pemberdayaan Masyarakat dan Desa Kelurahan Kasongan Baru, jika ada keluhan dari masyarakat terkait Bansos Rastra dapat menyampaikan kepada Kelurahan melalui staf yang ada di Kelurahan dan di proses oleh bagian Pemberdayaan Masyarakat dan Desa. Jika dilihat dari peran aktor dalam penyaluran beras sejahtera di KelurahanKasongan Baru sudah dapat di katakan berjalan sesuai dengan ketentuan serta aturan yang berlaku dan setiap Pegawai Kelurahan sudah menjalankan tugas dan fungsinya masing-masing.

Jika dilihat kondisi sosial, ekonomi, dan budaya masyarakat Keluarga Penerima Manfaat beras sejahtera di Kelurahan Kasongan Baru masih sedikit tertinggal dari masyarakat-masyarakat yang ada di Kelurahan Kasongan Baru, hal tersebut terlihat dari tingkat pendidikan, pekerjaan, penghasilan dan tempat tinggal dari Keluarga Penerima Manfaat beras sejahtera di Kelurahan Kasongan Baru. Karena masalah sosial dapat menimbulkan perbedaan yang mencolok diantara masyarakat seperti ada batas pemisah dalam interaksi atau komunikasi antara orang berada di tingkatan yang dibawah dan diatasnya dan juga dalam segi ekonomi yang sangat berpengaruh terhadap lingkungan di karenakan penduduk yang ekonominya berada dibawah garis kemiskinan akan berlomba-lomba mencari lahan kritis dan lahan-lahan konservasi sebagai tempat pemukiman. Lahan-lahan yang seharusnya berfungsi sebagai kawasan penyangga atau mempunyai fungsi konservasi terebut alan kehilangan fungsi lingkungannya setelah dimanfaatkan untuk kawasan pemukiman.

Akibat dari hal yang sudah disebutkan tersebut maka akan terjadinya ketidakseimbangan lingkungan yang dapat menyebabkan banyak terjadinya bencana alam seperti banjir serta tanah longsor. Dan juga Keadaan ekonomi keluarga berhubungan erat dengan belajar anak, karena fasilitas belajar itu hanya dapat terpenuhi jika keluarga mempunyai cukup uang sehingga mengakibatkan mereka tidak mampumemberikan pendidikan yang cukup bagi anakanaknya terutama dalam pendidikan formal. Jika keluarga mempunyai pendapatan dibawah ratarata maka hal tersebut dapat akan mempengaruhi kesehatan anak yang dapat menggangu pendidikan sang anak. Di Kelurahan Kasongan Baru ada beberapa Keluarga Penerima Manfaat beras sejahtera yang mendapatkan bantuan dana dari pemerintah untuk pendidikan anak, walaupun tidak seluruh Keluarga Penerima Manfaat yang mendapatkannya tetapi hal tersebut sudah dapat membantu masyarakat kurang mampu dalam memberikan pendidikan yang cukup untuk anaknya. Dan juga ada beberapa KPM yang mendapatkan bantuan bedah rumah dari pemerintah untuk masyarakat kurang mampu yang sudah memiliki tanah untuk dapat dibangunkan rumah, hal ini juga sudah dapat membantu masyarakat walaupun tidak semua masyarakat kurang mampu di Kelurahan Kasongan Baru. Jika dilihat dari segi budaya, masyarakat penerima beras sejahtera di Kelurahan Kasongan Baru masih banyak yang bekerja serabutan seperti memancing, memberi makan sapi atau ayam, yang mana dari hal tersebut belum bisa untuk 
memenuhi seluruh kebutuhan dari Keluarga Penerima Manfaat.

$$
\text { Adapun faktor pendukung dari }
$$

implementasi Bantuan Sosial Beras Sejahtera di Kelurahan Kasongan Baru yaitu cepatnya Pegawai Kelurahan menyampaikan surat pemberitahuan dari Lurah kepada setiap Ketua RT di Kelurahan Kasongan Baru setelah mendapat surat pemberitahuan dari Kecamatan Katingan Hilir bahwa beras akan di kirim ke setiap Kelurahan dan Desa serta sudah sesuainya dengan Pedoman Umum Bantuan Sosial Beras Sejahtera yang menyatakan bahwa berasdi berikan secara gratis dan tidak di pungut biaya apapun dari setiap Keluarga Penerima Manfaat saat pengambilan Beras, serta seluruh pegawai di Kelurahan Kasongan Baru terlibat dalam membagikan beras kepada setiap KPM dan juga banyaknya pegawai kelurahan yang terlibat saat penyaluran beras kepada masyarakat dapat mempengaruhi saat penyaluran di karenakan banyaknya Keluarga Penerima Manfaat yang datang mengambil jatah beras masing-masing. Serta Kelurahan tidak mengharuskan nama Keluarga Penerima Manfaat yang terdaftar harus datang mengambil beras di Kelurahan, dapat di wakilkan selama pegawai Kelurahan kenal bahwa yang mewakilkan itu adalah saudara atau anak dari KPM dan faktor pendukung lainnya yaitu tidak terlalu jauhnya jarak dari Kantor Kelurahan Kasongan Baru dengan rumah setiap Keluarga Penerima Manfaat beras sejahtera yang mana hal ini dapat memudahkan masyarakat Keluarga Penerima Manfaat pada saat pengambilan beras dikarenakan ada beberapa Keluarga Penerima Manfaat yang sudah lanjut usia.

Dan faktor penghambat dari implementasi Bantuan Sosial Beras Sejahtera di Kelurahan Kasongan Baru yaitu kurangnya komunikasi antar masyarakat dan Kelurahan Kasongan Baru terhadap masalah atau keluhan yang di rasakan masyarakat, serta waktu kedatangan beras yang tidak menentu bahkan pernah di pertengahan tahun 2018 beras datang sampai 5 bulan sekali, hal tersebut dapat menjadi faktor penghambat bagi program Bantuan Sosial Beras Sejahtera. Faktor penghambat lainnya yaitu Data Penerima Manfaat yang masih memakai data yang lama dan tidak berganti atau tidak adanyaperubahan/pembaharuan data, hal ini dapat menjadi penghambat karena beberapa Keluarga Penerima Manfaat yang menerima mungkin sudah tidak masuk kriteria penerima manfaat Bansos Rastra di Kelurahan Kasongan Baru.

Hal tersebut memperlihatkan bahwa kurang tanggapnya Dinas Sosial dan Kelurahan Kasongan Baru atas Data Penerima Manfaat Bansos Rastra, seharusnya kelurahan yang terlibat langsung di masyarakat dan kenal dengan masyarakat yang ada di Kelurahan Kasongan Baru dapat mengajukan beberapa nama untuk penambahan atau mungkin pergantian nama dalam Data Penerima Manfaat. Dan Kelurahan seharusnya mengetahui jika ada Keluarga Penerima Manfaat yang pindah rumah dan tidak berdomisi di Kelurahan Kasongan Baru lagi tetapi masih menjadi Keluarga Penerima Manfaat Bansos Rastra di Kelurahan Kasongan Baru.

\section{KESIMPULAN}

Dapat disimpulkan bahwa peran aktor pelaksana dalam Implementasi Program Bantuan Sosial Beras Sejahtera di kelurahan Kasongan Baru Kecamatan Katingan Hilir sudah berjalan sesuai dengan ketentuan dan aturan yang berlaku tetapi memang masih ada beberapa masalah jika dilihat dari beberapa faktor seperti :

I. Komunikasi pegawai Kelurahan dengan Masyarakat terkait Program Bansos Rastra dan saat pengambilan beras Kelurahan Kasongan Baru hanya menginformasikan melalui masing-masing ketua RT dengan informasi tertulis berupa surat pengambilan Beras Sejahtera yang menurut Kelurahan cara tersebut dirasa sudah maksimal namun jika dilihat dari kenyataannya di lapangan cara tersebut masih belum sepenuhnya berhasil 
untuk menyampaikan informasi dengan baik hingga sampai kepada setiap Keluarga Penerima Manfaat.

2. Kurang tepatnya beberapa sasaran Keluarga Penerima Manfaat Program Bansos Rastra di karena ada beberapa Keluarga Penerima Manfaat yang sudah pindah rumah tetapi masih terdaftar sebagai penerima Beras Sejahtera di Kelurahan Kasongan Baru.

3. Data Penerima Manfaat Bansos Rastra di Kelurahan Kasongan Baru yang tidak berganti dan masih memakai Data Penerima Manfaat tahun 2013 yang mana data tersebut dibuat saat nama program masih memakai nama Program Beras Miskin (Raskin), di tahun 2018 Pemerintah telahmenetapkan kebijakan transformasi Program Raskin menjadi Program Bantuan Sosial Beras Sejahtera. Serta rumitnya persyaratan pengajuan perubahan Data Penerima Manfaat Program Bansos Rastra dan juga lamanya proses verifikasi data pergantian Keluarga Penerima Manfaat Bansos Rastra.

\section{REFERENSI}

Barata, Atep. 2004. Dasar-dasar Pelayanan Prima. Jakarta : Elex Media. Komputindo.

Dunn, William N. 2003. Analisis Kebijakan Publik. Yogyakarta: Gadjah Mada University Press.

Islamy, Irfan. 2007. Prinsip-Prinsip Perumusan Kebijakan Negara. Jakarta: Bumi Aksara

Kasmir. 2006. Manajemen Perbankan. Jakarta : PT. Raja Grafindo Persada.

Madani, Muhlis. 20II. Interaksi Aktor dalam Proses Perumusan Kebijakan Publik. Yogyakarta: Graha IImu

Rustanto, Bambang. 20I5. Menangani Kemiskinan. Bandung: PT Remaja Rosdakarya.

Sinambela, Lijan Poltak. 2015. Reformasi Pelayanan Publik. Jakarta: Bumi Aksara.

Sugiyono. 2016. Metode Penelitian. Bandung : Alfabeta.

Suharto, Edi. 201I. Kebijakan Sosial sebagai Kebijakan Publik. Bandung: Alfabeta.

Usman, 2002. Implementasi Berbasis Kurikulum. Jakarta: PT Raja

Wahab, Solichin Abdul. 2004. Analisis Kebijaksanaan Dari formulasi Ke Implementasi Kebijaksanaan Negara. Jakarta: Bumi Aksara.

Wahab, Solichin Abdul. 2012. Analisis Kebijakan dari Formulasi ke penyusunan Model-model Implementasi Kebijakan Publik. Malang: Paragonatama Jaya.

Wibawa, Samodra. 201I. Politik Perumusan Kebijakan Publik. Yogyakarta: Graha IImu

Winarno, Budi. 2012. Kebijakan Publik: Teori, Proses dan Studi Kasus. Yogyakarta : Media Pressindo. 